\title{
Improvement of diagnostics and complex treatment of rhinosinusogenic orbital complications in children
}

\section{Nilufar KHUSHVAKOVA ${ }^{1}$ Shukhrat ULASHOV ${ }^{2}$ Gulrux DAVRONOVA ${ }^{3}$}

Samarkand State Medical Institute

\section{ARTICLE INFO}

Article history:

Received February 2021

Received in revised form

20 February 2021

Accepted 15 March 2021

Available online

5 April 2021

\footnotetext{
Keywords:

rhinosinusogen in children, orbital complications, diagnosis,

pediatrics,

complex therapy,

diagnosis and complex

treatment.
}

\begin{abstract}
The article discusses ways to improve the diagnosis and complex treatment of rhinosinusogenic orbital complications in children. It also covers the scientific and theoretical work of scientists studying the diagnosis and complex treatment of rhinosinusogenic orbital complications in children, as well as recommendations for improving the diagnosis and complex treatment of rhinosinusogenic orbital complications in children.
\end{abstract}

2181-1415/C) 2021 in Science LLC.

This is an open access article under the Attribution 4.0 International (CC BY 4.0) license (https://creativecommons.org/licenses/by/4.0/deed.ru)

\section{Болаларда риносинусоген орбитал асоратларни ташхислаш ва комплекс даволашни такомиллаштириш}

\author{
Калит сўзлар: \\ болалардаги \\ риносинусоген, \\ орбитал асоратлар, \\ ташхис, ташхис ва \\ комплекс даволаш, \\ болалар касалиги, \\ комплекс даволаш.
}

\begin{abstract}
АННОТАЦИЯ
Мазкур мақолада болалардаги риносинусоген орбитал асоратларни диагностикаси ва комплекс даволашни такомиллаштириш йўллари ёритилган. Шунингдек, болалардаги риносинусоген орбитал асоратларни диагностикаси ва комплекс даволашни ўрганган олимларнинг илмий-назарий ишлари ёритилган. Бундан ташқари, болалардаги риносинусоген орбитал асоратларни диагностикаси ва комплекс даволашни такомиллаштириш йўллари бўйича таклифлар берилган.
\end{abstract}

\footnotetext{
${ }^{1}$ Professor of Samarkand State Medical Institute. Samarkand, Uzbekistan.

E-mail: nilumedlor@mail.ru.

${ }^{2}$ Assistant of Samarkand State Medical Institute. Samarkand, Uzbekistan.

${ }^{3}$ Assistant of Samarkand State Medical Institute. Samarkand, Uzbekistan.

E-mail: davronova.gulrux@mail.ru.
} 


\section{Совершенствование диагностики и комплексное лечение риносинусогенных орбитальных осложнений у детей}

\author{
Ключевые слова: \\ риносинусоген у детей, \\ орбитальные осложнения, \\ диагностика, детские \\ болезни, комплексная \\ терапия, диагностика и \\ комплексное лечение.
}

\begin{abstract}
АННОТАЦИЯ
В статье рассматриваются пути совершенствования диагностики и комплексного лечения риносинусогенных орбитальных осложнений у детей. Он также охватывает научно-теоретические работы ученых, изучающих диагностику и комплексное лечение риносинусогенных орбитальных осложнений у детей, а также рекомендации по совершенствованию диагностики и комплексному лечению риносинусогенных орбитальных осложнений у детей.
\end{abstract}

\section{INTRODUCTION}

Over the past decades, the method of computed tomography (CT) has become firmly established in practice as the most significant and effective in the diagnosis of pathology of the paranasal sinuses and the cranial cavity (Voronkin V.F. et al., 1998; Deryugina O.V. et al., 2002; Lebedeva M.A. et al., 2005). Therefore, it becomes necessary to analyze and systematize the computed tomographic signs of intracranial complications and sinusitis. During the surgical treatment of the primary focus of infection in the paranasal sinuses, most otolaryngologists prefer a wide extranasal opening of the affected sinuses (Volfkovich M.I., 1963; Pal-chun V.T. et al., 1977). But with a severe condition of the patient, massive surgical intervention can aggravate the patient's condition. Therefore, the question of the use of sparing methods of operative sanitation of the paranasal sinuses in case of rhinosinusogenic intracranial complications is relevant [1].

When carrying out antibiotic therapy, it is extremely important to create an optimal and constant level of drug concentration in the blood and cerebrospinal fluid, which can be achieved by intra-arterial administration of drugs. In accordance with the set objectives of the study, we developed a thematic map for each patient, in which passport data, complaints, medical history, results of clinical and objective research, a description of the endoscopic picture of the nasal cavity, data of special functional and laboratory studies were entered. All patients with suspected intracranial complications underwent otorhinolaryngological, neurological, laboratory and X-ray examinations. Consultations of a neurosurgeon, ophthalmologist, immunologist, pediatrician, resuscitation specialist and other specialists were prescribed as needed. Also, if necessary, a lumbar puncture was prescribed. The laboratory research concerned generally accepted indicators of the inflammatory process, hemostatus, as well as parameters functioning of the organs and systems concerned. All patients, in addition to performing anterior and posterior rhinoscopy, underwent endoscopic examination of the nasal cavity using rigid endoscopes from Storz or Eleps with 0, 30, 70 optics. For all patients, we performed a general $\mathrm{X}$-ray of the paranasal sinuses in the noso-chin and lateral projections, computed tomography of the paranasal sinuses [2].

Assessment of the functional state of the nasal mucosa, its excretory and absorption functions, mucociliary clearance was carried out using a polymeric water-soluble film of hydroxypropyl methylcellulose (OPMC) containing saccharin and methylene blue. In everyday clinical practice, we used the Rhinomanometer PC 200 computer 
rhinomanometer (ATMOS, Germany), which allows anterior active rhinomanometry (PARM). A group of patients was examined blood to determine the parameters of the immunological aspect of the anti-infectious resistance system[3]. The sections of the mucous membrane removed during endoscopic interventions were subjected to histological examination. To determine the microflora of the nasal cavity and paranasal sinuses, bacteriological inoculation of the contents of the nasal cavity was performed.

\section{LITERATURE REVIEW}

Acute inflammatory diseases of the paranasal sinuses (SNP) are an urgent problem in the practice of a pediatric otorhinolaryngologist. Orbital complications of acute sinusitis, especially severe forms (subperiostal abscess, retrobulbar abscess, phlegmon of the orbit) can not only lead to irreversible changes in the organ of vision, up to blindness, but also cause life-threatening conditions (sepsis, intracranial complications). This determines the need for timely diagnosis of this pathology, as well as intensive, adequate, individualized treatment tactics (Dobromylsky F.I., Shcherbatov I.I., 1961; Budilov Yu.K., 1978; Soldatova V.V., 1985; Kruchinina I.L., 1985, 1989; Garashchen-ko T.I., 1989, 1996) [4]. Conventional surgical methods for the treatment of orbital complications are aimed primarily at opening the affected paranasal sinuses and are very effective. However, they are not without drawbacks. Any endonasal intervention on SNP is performed in the immediate vicinity of such vital structures as the base of the skull, orbit, optic nerves, large vessels, therefore, it is associated with a certain risk of iatrogenic complications.

Back in 1929, H.P. Mosher called endonasal ethmoidectomy the most "blind" and dangerous operation in surgical practice. The likelihood of such consequences as rhino liquorrhea, meningitis, profuse bleeding and blindness is constantly discussed in rhinological literature (Freedman N.M., Kezn E.V., 1979; Maniglia AJ. Et al., 1981; Kane K., 1993; Hosemann WG et al., 2000)[5]. All these circumstances limit the actions of the surgeon and often lead to insufficient rehabilitation of the focus. In addition, with complicated forms of acute sinusitis, extranasal polysinusotomies and orbitotomies are still widely used, including in children (Mann W. et al., 1997; Reddy SC et al., 1999; Deryugina O.B, Chumakov F.I., 2001; Syrtlanov A.R., 2001), which leads to significant cosmetic defects, and in some cases to impaired growth and development of the facial skeleton (Yakushenkova A.P. et al., 2002) [6].

The introduction of endoscopic techniques into practice radically changed the approach to the diagnosis and treatment of sinusitis (Garashchenko T.I., 1986; Khutsiev A.M., 1989; Andzhaparidze Z.N., 1991; Piskunov G.Z., Lopatin A.S., 1992; Piskunov S.Z., 1995; Kozlov BC, 1995). In recent years, the methods of performing endoscopic interventions have been significantly modified, the indications for their use have expanded, including in pediatric practice (Kruchinina I.L., 1984; Shevrygin B.V., 1990; Sergeev S.V., 1990; Garashchenko T. H., 1996; Wolf G. et al., 1993) [7].

\section{RESEARCH METHODOLOGY}

The research used grouping, comparison, analysis, synthesis, induction, deduction, horizontal, vertical and factor analysis methods. In particular, the comparison method is the most basic method of improving diagnostics and complex treatment of rhinosinusogenic orbital complications in children tal analysis, which is also used in the 
analysis of financial results. In addition, the complex treatment of rhinosinusogenic orbital complications was analyzed in pediatric analysis using scientific approaches.

\section{ANALYSIS AND RESULTS}

The data obtained on endoscopic diagnosis and semiotics of diseases of the paranasal sinuses expand the understanding of the relationship between age-related structural features, as well as various anatomical anomalies of intranasal structures with the frequency and severity of acute sinusitis, including those with orbital complications, in children. In a large group of children, the incidence of complicated acute sinusitis was assessed, and the structural distribution of various types of orbital complications in terms of age was shown.The studies carried out have shown the high efficiency of the use of endonasal endoscopic methods of treatment, which at the same time have a number of significant advantages over conventional interventions: safety, functionality, purposefulness, sufficient volume.It is shown that the technique of surgical intervention in the treatment of orbital complications depends on the child's age, structural features of the nasal cavity, the type and nature of the complication.Algorithms for antibacterial therapy of complicated acute sinusitis have been developed depending on age, form of complication, severity of the process and previous treatment[8]. The use of endoscopy for diagnostic purposes showed a higher incidence of complicated sinusitis in the presence of various anatomical anomalies of the intranasal structures, which allows this category of patients to be identified as a risk group for the development of a complicated course of the inflammatory process and to plan reconstructive minimally invasive interventions in the nasal cavity in order to prevent recurrence of paranasal diseases. sinuses.

It has been shown that the use of endoscopic techniques in surgical interventions for orbital complications of acute sinusitis makes it possible to carry out more functional and less traumatic interventions, avoiding external access operations. Visual control significantly reduces the risk of iatrogenic complications, and allows full sanitation of the pathological focus. The types of endoscopic surgical interventions in children with sinusogenic orbital complications in different age groups have been developed.In the process of surgical intervention, for a sufficient and lasting effect, the altered intranasal structures are corrected, therefore, the risk of recurrence of the development of inflammatory diseases of the paranasal sinuses is reduced.An algorithm for stage-by-stage antibiotic therapy of complicated acute sinusitis in children has been created, which allows the use of individualized treatment regimens, taking into account the child's age, the type of complication, the severity of the process, previous therapy.The use of the developed algorithms will allow not only to carry out complex treatment of complicated acute sinusitis at the modern level, but also to reduce the risk of generalization of the infection, to help prevent the development of chronic forms of the disease.Rational use of antibacterial drugs will not only improve the quality of treatment, but also achieve a large pharmacoeconomic effect in the treatment technology of this category of patients.An isolated epidural abscess was diagnosed in one patient. In one case, a patient was observed with a combination of epidural abscess and encephalitis of the right frontal lobe of the brain. A sign of an epidural abscess on a computed tomogram was a limited formation of increased density with clear edges, lenticular shape, adjacent to the bones of the skull[9].

Meningoencephalitis occurred in five patients in the form of isolated forms of intracranial complications. In all patients, meningoencephalitis developed against the 
background of acute diffuse inflammation of the paranasal sinuses. The duration of the disease, according to the anamnesis, ranged from 4 days to 2 weeks. The computed tomographic sign was the presence of a zone of reduced density of the brain substance without clear boundaries, mainly in the frontal lobes of the brain. These data, characteristic of isolated encephalitis, were combined with the presence of meningeal symptoms in the clinical picture in all patients. Cavernous sinus thrombosis occurred in 10 patients. In five patients, thrombosis of the cavernous sinus was isolated, in the rest of the patients there was a different combination of intracranial complications. All patients underwent computed tomography. The duration of the disease varied according to the anamnesis from 3 days to 2 weeks. There was no clear evidence of cavernous sinus thrombosis on CT. Among the indirect signs, edema and infiltration of the retrobulbar cells were determined.

lesions, dilatation of the orbital veins, mainly of the superior orbital vein, which were noted by CT in all patients with cavernous sinus thrombosis.The main provisions for the defense[10]:

1. Diagnostic endoscopy for complicated acute sinusitis allows to detail the rhinoscopic picture, to carry out the correct diagnosis and to determine the adequate individualized tactics of conservative and surgical treatment.

2. The age-related features of endoscopic surgery in complicated acute sinusitis make it possible to carry out safer, targeted and functional interventions with maximum efficiency, taking into account the growth and development of the nasal cavity and paranasal sinuses.

3. The algorithm for antibacterial therapy of sinusogenic orbital complications is compiled taking into account the child's age, the extent of the lesions of the paranasal sinuses and the orbit, the likelihood of intracranial complications.

\section{CONCLUSIONS AND SUGGESTIONS}

1) In conclusion, improvement of diagnostics and complex treatment of rhinosinusogenic orbital complications in children developed the following proposals for development:

2) the main etiopathogenetic factor in the development of rhinosinusogenic intracranial complications is purulent widespread inflammation of the paranasal sinuses;

3 ) the complex use of computed tomography and endorinoscopic techniques at the diagnostic stage is decisive for the treatment tactics of managing patients with rhinosinusogenic intracranial complications;

4) the developed diagnostic and therapeutic algorithm makes it possible to increase the effectiveness of the treatment of intracranial rhinosinusogenic complications;

5) intra-arterial administration of antibiotics and heparin in the complex treatment of rhinosinusogenic intracranial complications has a high therapeutic effect.

\section{REFERENCES:}

1. Abdurashitov R.Sh. Clinical and electrophysiological parallelogram diagnostics of rhinogenic arachnoiditis / R.Sh. Abdurashitov, F.A. Khafizova // Ros. rhinology. 2002. №2. - P. 55-56.

2. Algorithm intensivnoy terapii otogennyx intracranial nyx oslojneniy u detey / G.V. Gvak, A.P. Sergeeva, E.G. Eremenko, S.P. Shamray // Novosti otorinolar i logopatol. 2002. - №1. -P. 33-35. 
3. Amcheslavskiy V.G. Modern therapy of abscesses in the brain / V.G. Amcheslavskiy, V.N. Shimanskiy, B.R. Shatvoryan // Rus. med. jurn. - 2000. - T.: 8. P. 533-537.

4. Antoniv V.F. Kompyuternaya tomografiya pr izabolevaniyax lobnyxpazux / V.F Antoniv, I.X. Rabkin, P.P. Masharipov // Vestn. otorhinolaryngology. - 1990. № 3. - P. 7-11.

5. Arefeva N.A. Complex diagnosis of rhinogenic arachnoiditis / N.A. Arefeva, R.Sh. Abdurashitov, F.A. Khafizova // Ros. rhinology. - 1998. - № 2. - P. 39.

6. Bacterio-immunologicheskaya characteristic bolnyx thrombosis peshcheristogo sinusa / I.A. Shulga, V.N. Shchetinin, M.V. Adamia and dr.// Ros. rhinology. - 1998. № 2. - P. 17.

7. Blagoveshchenskaya N.S Differential diagnosis of rhinosinusogenic cerebral leptomeningitis and abscesses of the brain / N.S. Blagoveshchenskaya, N.Z. Muxamedjanov // Jurn. neuropathology and psychiatry im. Korsakova. 1991. - № 2. - P. 34-36.

8. Yu. Blagoveshchenskaya, N.S. Rhinosinusogennte vnutricherepnыe oslojneniyai ix diagnostics at the modern stage / N.S. Blagoveshchenskaya / Vestn. orinolaryngology. 1992. № 1. - P. 1-5.

9. Blagoveshchenekaya N.S. Sochetannыe porazheniya lobnyx pazuximozga / N.S. Blagoveshchenskaya. M.: Medicine, 1972. - P. 272.

10. Bobrov V.M. Rhinosinusogenic abscesses in the brain / V.M. Bobrov, O.P. Kashnikova, I.N. Kuznetsova // Ros. Rhinology - 2003. - №1 - - . 56-57. 